\title{
Beyond reason: art and psychosis
}

\author{
Robert Chaplin and Josephine Richards
}

It is unusual for an exhibition of unknown artists to open with critical acclaim and draw crowds to a major gallery. What is more remarkable is that few of the artists received formal tuition, none belonged to a movement or painted commercially and they did not expect their work to be seen by an audience. The artists were mentally ill people residing in asylums throughout Europe whose work was collected between 1918 and 1921 by the German psychiatrist and art historian Hans Prinzhorn (1886-1933).

Prinzhorn believed that the art was valuable, not for the study of the psychopathology of the artists, but because of its own artistic merit. This concept was preserved in the exhibition as no diagnostic

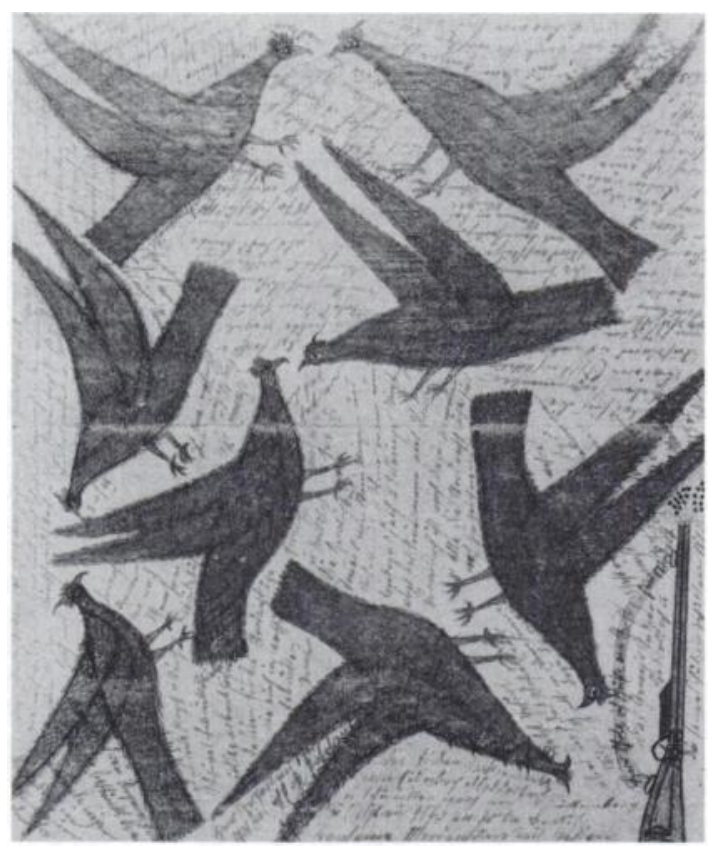

Figure 1. The marvels the lead-shot to the sporting gun, Johann Knopf. Hayward Gallery 5 December 1996 to 2 March 1997. Reproduced courtesy of the Prinzhorn Collection labels were given to the artists. There are considerable variations in the levels of skill and ability among the artists and in the materials they used. Many worked with scraps of waste paper such as calendars, office paper, toilet paper, newspaper, cardboard and other readily available materials such as old cloth or handkerchiefs.

There is no unifying theme to the exhibition except the status of the artists. Karl Gustav Seivers (see Fig 1) and Frans Joseph Kleber have detailed the architecture of their hospitals. There is surprisingly little representation of life inside the asylums except for the work by Carl Lange. He includes an extract of writing which tells of his solitary confinement. He also claims to have witnessed a patient who "they had perversely forced to choke down medicines conductve to insanity. . . had died of this poisoning".

The majority of the work seems to depict the inner worlds of the artists and their unusual personal experiences (see Fig 2). Therefore it is difficult as a psychiatrist to try to view the works in isolation from their mental states. The images often appear to be the expression of some unique, private, terrifying experience. We are given a view of patients treated in the preneuroleptic era and the florid and enduring nature of the symptoms they must have suffered. An example is the weightlessness of Joseph Forster's blindfolded floating man secured to the ground by ropes, the image used to advertise the exhibition. Reference to the catalogue confirms that most of the artists suffered from psychosis (most commonly dementia praecox).

The exhibition examines the influence that these artists had on their mainstream contemporaries. August Natterer, who painted the miraculous shepherd in 1919 and later died in the Rottweil Asylum, is reputed to have been the first artist to paint in the surrealist style, and may have served as an inspiration to the renowned Max Ernst. Prinzhorn likened the work of one of the patient artists to that of Emile Nolde. This association resulted in the latter subsequently being discredited by the Nazis.

The most distressing feature of the exhibition is not the depiction of the disturbed states of 


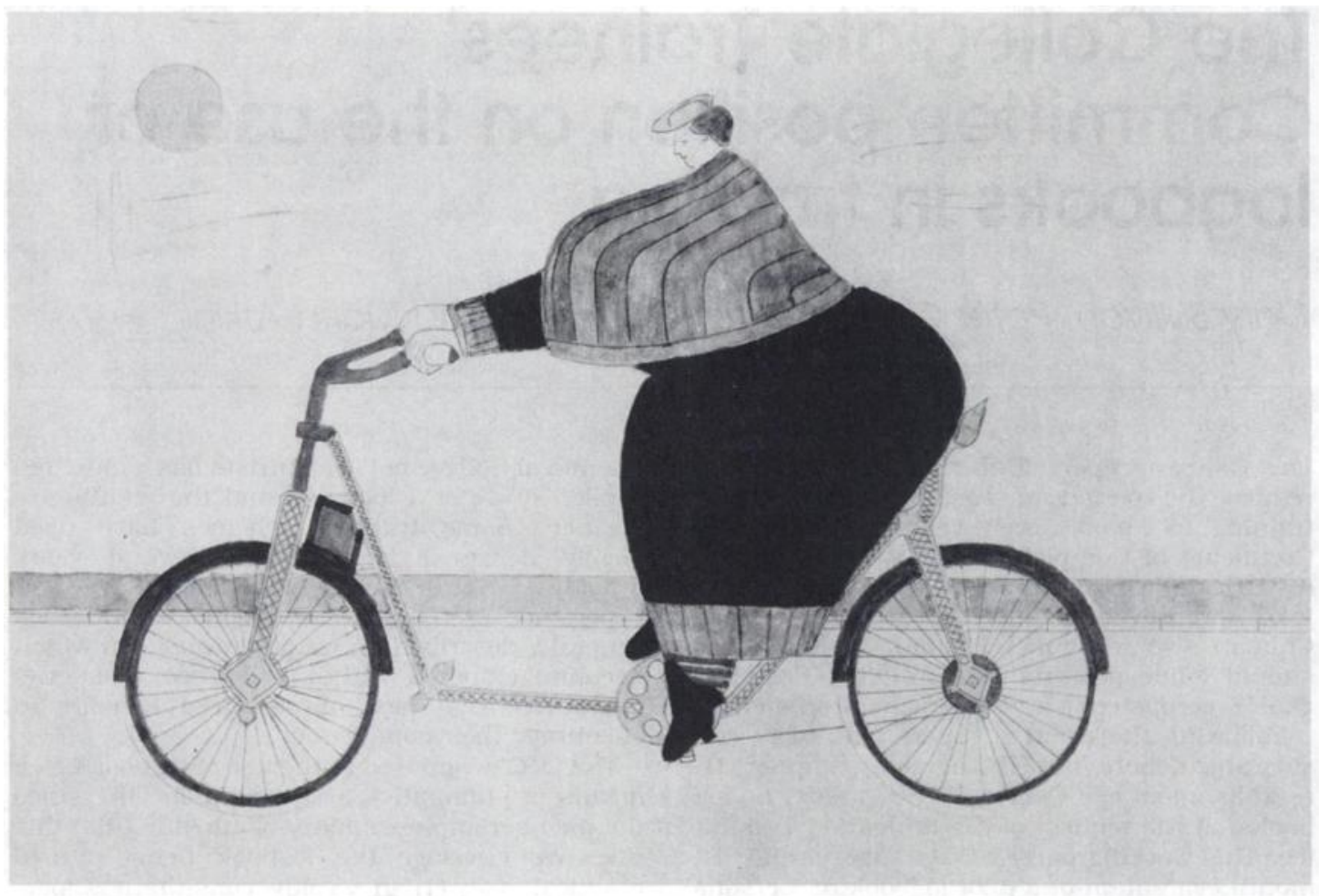

Figure 2. Untitled, Karl Gustav Sievers. Hayward Gallery 5 December 1996 to 2 March 1997. Reproduced courtesy of the Prinzhorn Collection

mind of the artists or the conditions of deprivation in which they lived, but the fate of some of them: murdered by the Nazis. Most of these artists did not show an awareness in their art of political changes happening outside the institutions and yet many later became victims of Hitler's regime. The viewer does however obtain a glimpse of this world through the work of August Johann Klose who used a picture of a German soldier from a war leaflet mounted on toilet paper in a collage.

Although the collection survived the Nazi administration, it was not afforded the status of art by Carl Schneider who later took charge of it. After $\mathbf{3 0}$ years of neglect, the collection has fortunately been renovated and displayed over the last three decades. The current exhibition serves both as a grim reminder of the history of ethnic cleansing of people with mental illness, and to rehabilitate their art.
Beyond reason: art and poychosis was shown at the Hayward Gallery, London until February 23. 1997 and is at the Kulturgeschichtliches Museum,Osnabruch Germany Aprll 6-June 1 1997.

\section{Reference}

Beyond reason: art and psychosis. Works from the Prinzhom collection (1996) Catalogue and leaflet. London: Hayward Gallery.

*Robert Chaplin, Consultant Psychiatrist, Springfield Hospital, London; and Josephine Richards, Senior Registrar, Department of Child and Adolescent Psychiatry, St. George's Hospital, London

*Correspondence 